\title{
BIMBINGAN KELOMPOK MENINGKATKAN KOMUNIKASI ANTAR SISWA TUNAGRAHITA DAN TUNARUNGU DENGAN PEMBUATAN DRAMA MUSIKAL DI SLB-C NEGERI PEMBINA PROVINSI KALIMANTAN SELATAN
}

\author{
RR. Ambar Purwaningtyas \\ SLB-C Negeri Pembina Provinsi Kalimantan Selatan
}

\begin{abstract}
ABSTRAK
Penelitian ini dilatarbelakangi oleh pengamatan guru BK mengenai komunikasi antar anak tunagrahita dan tunarungu di kelas SMPLB masih sangat kurang. Bahkan bisa dikatakan hampir tidak ada. Tujuan dari penelitian ini adalah untuk meningkatkan komunikasi antar anak tunagrahita dan tunarungu di SMPLB dengan bimbingan kelompok merencanakan proyek drama musikal bersama guru sendratasik, dan guru tunarungu. Penelitian ini merupakan penelitian deskriptif dengan pendekatan kualitatif. Teknik pengumpulan data yang digunakan adalah dengan teknik observasi dan dokumentasi. Hasil penelitian menunjukkan peningkatan komunikasi pada anak tunagrahita dan tunarungu setelah proyek drama musikal. Evaluasi yang dilakukan berupa evaluasi proses dan evaluasi hasil dalam pelaksanaan kegiatan layanan bimbingan kelompok. Adapun kesimpulan dari penelitian ini menunjukkan peningkatan komunikasi antar siswa tunagrahita dan tunarungu setelah mengikuti kegiatan bimbingan kelompok berupa proyek pembuatan drama musikal.
\end{abstract}

Kata kunci: bimbingan kelompok, komunikasi siswa, tunagrahita, tunarungu, drama musikal

\section{PENDAHULUAN}

Salah satu anak berkebutuhan khusus adalah anak tunagrahita dan tunarungu. Tunagrahita adalah anak dengan keterbelakangan mental. Sedangkan tunarungu adalah anak dengan indra pendengarannya rusak.

"Anak tunagrahita mempunyai kemampuan intelektual di bawah rata-rata. Yang mana memiliki arti sama yang menjelaskan kondisi anak yang kecerdasannya di bawah rata-rata dan ditandai oleh keterbatasan intelegensi dan tidak cakapan dalam interaksi sosial" (Somantri, 2007:103). Dari paparan ini dapat kita simpulkan bahwa anak tunagrahita memiliki keterbatasan dan tidak cakapan dalam berinteraksi. Saat mereka harus berinteraksi dengan anak tunarungu yang mempunyai cara berkomunikasi berbeda dengan orang biasa tentu saja mereka akan kesulitan.

"Anak tunarungu dapat berkomunikasi secara verbal/oral artinya mampu mengungkapkan, menanyakan, memperbincangkan sesuatu secara oral dan juga berkomunikasi secara nonverbal seperti gerak tubuh, mimik muka, dan bahasa yang berupa isyarat" (Bintoro, 2011). Selain dengan bahasa isyarat anak tunarungu dapat berkomunikasi dengan orang lain menggunakan komunikasi verbal/oral. Hanya saja tidak semua anak tunarungu di SLB-C Negeri Pembina dapat berkomunikasi secara oral. Kemampuan komunikasi secara oral ini dipengaruhi oleh tingkat ketulian dan kemampuan guru dan juga sarana prasarana pembelajaran di sekolah.

Menurut Andreas Dwidjosumarto (Sutjihati Somantri, 2007) mengatakan bahwa seseorang yang tidak atau kurang mampu mendengar suara dikatakan tunarungu. Tunarungu dibedakan menjadi 2 kategori, yaitu: tuli (deaf) dan kurang dengar (hard of hearing). Tuli adalah anak yang indra pendengarannya mengalami kerusakan taraf berat sehingga tidak 
Jurnal Inovasi BK, Volume 2, Nomor 1 Juni 2020

berfungsi lagi. Kurang dengar adalah anak yang indra pendengarannya mengalami kerusakan tetapi masih dapat mendengar baik dengan atau tanpa alat bantu dengar. Di SLB-C Negeri Pembina beberapa anak yang masuk dalam kategori kurang dengar ini dapat berkomunikasi secara oral. Walaupun pengucapan mereka tidak terlalu jelas.

Agar komunikasi antar anak tunagrahita dan tunarungu di SMPLB dapat meningkat dan tercipta keakraban antar mereka, maka guru BK bekerja sama dengan guru sendratasik dan guru dari kelas tunarungu membuat proyek drama musikal. Dengan berkumpul dan latihan bersama selama 1 bulan dengan didampingi oleh guru diharapkan anak tunagrahita dan tunarungu dapat berkomunikasi dan tercipta keakraban di antara mereka.

Pada penelitian terdahulu yang dilakukan Cahyaningrum (2014) tentang Pembentukan Kemampuan Kerjasama Pada Anak Tunagrahita Ringan dalam Pembuatan Batako di SLB Mardi Mulyo Bantul menunjukkan bahwa semakin meningkatnya intensitas komunikasi dapat membuat siswa mengenal individu satu dengan individu lainnya dan pada akhirnya tidak mengalami kesulitan untuk bekerja sama dengan individu lain.

Lelyana (2017) dalam penelitiannya berjudul Interaksi Sosial Antar Anak Tunarungu dan Anak Tunarungu dengan "Anak Dengar" mengungkapkan bahwa kontak sosial dan komunikasi terjadi dalam interaksi sosial antar anak tunarungu dan "anak dengar". Interaksi sosial antar anak tunarungu tampak dalam ajakan bermain, mendekati sesama teman tunarungu, berkomunikasi baik secara oral maupun bahasa isyarat dalam bentuk abjad atau gerak tubuh. Selain itu, mereka juga melibatkan ekspresi perasaan dalam beragam bentuk baik mimik wajah ataupun tingkah laku.

Anak tunarungu tampak lebih pasif karena menunggu ajakan interaksi "anak dengar" ketika sedang bersama. Anak tunarungu berkomunikasi dengan cara menggerakkan bibir atau menuliskan pesan.

Brtdasarkan hasil penelitian tersebut, guru BK mengasumsikan bahwa intensitas berkumpulnya siswa tunagrahita dan tunarungu perlu ditingkatkan untuk dapat meningkatkan kemampuan dan rasa percaya diri siswa untuk berkomunikasi. Selain itu, anak tunagrahita perlu lebih aktif dalam mengajak anak tunarungu untuk berkomunikasi. Dan juga akan lebih membantu jika anak tunagrahita dapat berkomunikasi dengan pesan atau tulisan.

\section{METODE}

Penelitian ini merupakan penelitian deskriptif dengan pendekatan kualitatif. Menurut Sugiyono (2015:14) pendekatan kualitatif sering disebut pendekatan naturalistik karena penelitiannya dilakukan pada kondisi yang alamiah yang bertujuan untuk mengumpulkan informasi secara aktual dan terperinci, mengidentifikasi masalah, membuat perbandingan atau evaluasi, dan mengetahui bagaimana pelaksanaan layanan bimbingan kelompok. Penelitian ini dilakukan di SLB-C Negeri Pembina Provinsi Kalimantan Selatan pada bulan Maret 2019.

Peneliti merupakan instrumen kunci dalam penelitian kualitatif. Kehadiran peneliti mutlak diperlukan dalam penelitian kualitatif. Peneliti berperan sebagai pengamat penuh dalam mengumpulkan data di lapangan

Data diperolah dari observasi yang dilakukan olah guru BK. Data dalam penelitian ini adalah tentang pelaksanaan layanan Bimbingan Kelompok dengan membuat drama musikal bagi anak tunagrahita dan tunarungu di SLB-C Negeri Pembina Provinsi Kalimantan Selatan.

\section{HASIL DAN PEMBAHASAN}

Kegiatan Bimbingan Kelompok dilaksanakan dengan membuat proyek drama musikal yang akan ditampilkan pada 
acara perpisahan tahun ajaran 2018/2019 di SLB-C Negeri Pembina. Guru BK bekerja sama dengan guru Sendratasik dan guru Tunarungu mendampingi siswa dalam proses latihan dan perekaman video drama musikal. Proses latihan sendiri dilaksanakan pada bulan Maret 2019 selama 1 bulan. Dan perekaman video dilaksanakan selama 3 hari tanggal 8 - 10 April 2019. Hasil dari video drama musikal dapat dilihat pada link berikut

https://www.youtube.com/watch?v=mADyi shIVAc\& $=20$ s atau https://www.youtube.com/watch? $\mathrm{v}=\mathrm{Y} l \mathrm{khFv}$ eYGNU .

Proses pengambilan video dari drama musikal ini melibatkan hampir seluruh siswa SLB-C Negeri Pembina. Akan tetapi, dalam proses latihan gerak dan lagu, menyanyi, dan bahasa isyarat yang akan ditampilkan di video hanya beranggotakan siswa tunagrahita dan tunarungu di SLB-C Negeri Pembina. Mayoritas siswa yang terlibat adalah siswa dari jenjang SMPLB. Subyek penelitian ini adalah siswa tunagrahita kelas VIII-C(1) dan VIII-C(2) serta siswa tunarungu kelas VIII-B dan IX-B.

Anak berkebutuhan khusus mempunyai keterbatasan dalam berkomunikasi terutama menggunakan kata dan merangkai kalimat. Keterbatasan ini tidak hanya dimiliki siswa tunarungu tapi juga siswa tunagrahita. Akan tetapi mereka masih bisa mengerti kalimat-kalimat sederhana dengan kata kunci. Siswa tunagrahita dan tunarungu yang merupakan mayoritas dari siswa yang ada di SLB-C Negeri Pembina mempunyai hubungan pertemanan yang eksklusif. Siswa tunagrahita hanya bermain dan bercanda dengan sesama siswa tunagrahita. Dan siswa tunarungu hanya bermain dan bercanda dengan sesama siswa tunarungu.

Anak tunagrahita mengalami kesulitan dalam berinteraksi sosial. Ketidakmampuan anak tunagrahita ringan dalam berinteraksi tidak hanya disebabkan oleh faktor intelegensi yang rendah tetapi juga dipengaruhi oleh faktor lingkungan sosialnya. Tanpa interaksi sosial, kehidupan bersama tidak mungkin ada. Melalui suatu kegiatan tertentu kita dapat melihat bagaimana anak tunagrahita berinteraksi dengan sosialnya.

Anak tunarungu dikarenakan kondisinya mengalami banyak hambatan dalam berkomunikasi. Penggunaan berbagai cara berkomunikasi berupa komunikasi verbal (oral) dan non verbal (isyarat, gerak bibir, gerak tubuh, tulisan, ejaan jari) dapat digunakan untuk berkomunikasi dengan anak tunarungu. Penggunaan bahasa verbal dan nonverbal terlihat ketika siswa tunarungu berada di dalam kelas maupun di luar kelas. Proses komunikasi anak tunarungu dengan sesamanya dan dengan orang yang bisa mendengar memiliki keunikan dan kekhasan tersendiri. Keterbatasan pendengaran anak tunarungu menyebabkan mereka mengalami perlambatan perkembangan IQ, emosional, bergaul dengan masyarakat sehingga mereka kesulitan memahami realitas sosial. Bahasa lisan memiliki struktur kata yang juga berkaitan dengan makna. Anak tunarungu mungkin tahu kata tapi tidak tahu maknanya. Begitu juga mungkin mereka tahu obyek fisik tapi tidak tahu namanya. Hal ini mendorong mereka menciptakan bahasa sendiri dan sistem-sistem bahasa yang juga mereka ciptakan.

Agar anak tunagrahita dan tunarungu dapat berkomunikasi dapat menggunakan bahasa verbal (oral) ataupun nonverbal (berupa isyarat, gerak bibir, gerak tubuh, isyarat huruf, ataupun tulisan). Bahasa yang digunakan pun tidak perlu berupa kalimat lengkap. Anak dapat mengungkapkan pikirannya dengan kalimat-kalimat pendek ataupun hanya dengan kata kunci. Yang terpenting dari komunikasi adalah tersampaikannya pesan. Salah satu contoh adalah saat siswa 
Jurnal Inovasi BK, Volume 2, Nomor 1 Juni 2020 tunagrahita ingin mengajak siswa tunarungu untuk latihan, hanya perlu menggunakan bahasa tubuh atau isyarat kata latihan. Dalam proses bimbingan kelompok dengan pembuatan drama musikal ini, guru akan memfokuskan penggunaan kata kunci dan kalimat sederhana untuk membangun komunikasi antar anak tunagrahita dan tunarungu.

Persiapan pembuatan drama musikal dilakukan sebelum mengajak siswa untuk latihan. Guru BK, sendratasik, dan tunarungu membicarakan kerangka cerita yang akan ditampilkan, lagu yang akan digunakan, dan siswa yang akan menjadi pemain kunci di setiap adegan. Setelah itu, guru memberitahukan kepada siswa untuk berkumpul di aula dan membicarakan rencana guru untuk membuat proyek drama musikal yang akan ditampilkan di acara perpisahan.

Dalam proses latihan inilah guru BK membimbing siswa untuk mau berkomunikasi dengan teman yang mempunyai ketunaan lain. Terutama pada siswa tunagrahita, guru BK memberikan pemahaman bahwa merekalah yang harus terlebih dahulu aktif dan mengajak teman tunarungu untuk berkomunikasi. Sedangkan bagi anak tunarungu, guru BK meminta bantuan dari guru tunarungu untuk mendampingi dalam proses memberikan pemahaman pada siswa tunarungu agar mau mengajarkan maksud dari isyarat yang mereka gunakan kepada teman tunagrahita saat mereka berkomunikasi.

Upaya yang dilakukan guru BK selama proses latihan dan perekaman guna meningkatkan komunikasi antar siswa tunagrahita dan tunarungu adalah sebagai berikut:

- Pertama-tama memberikan pemahaman kepada siswa tentang perbedaan cara berkomunikasi dengan siswa tunarungu dan bagaimana bersikap baik kepada teman. Baik itu dengan teman yang sama jenis ketunaannya ataupun berbeda jenis ketunaannya.
Memberi contoh langsung pada siswa tunagrahita bahasa isyarat sederhana kepada siswa tunagrahita.

- Memberi pemahaman pada siswa tunarungu agar mau mengajarkan bahasa isyarat kepada siswa tunagrahita dengan menuliskan arti dari gerakan isyarat yang mereka gunakan

- Memberi tugas kepada siswa tunagrahita untuk memberitahukan pesan guru kepada siswa tunarungu dan sebaliknya.

Pada minggu pertama latihan berlangsung belum terlihat adanya komunikasi yang intens antara siswa tunarungu dan tunagrahita. Setelah guru memberikan pemahaman kepada siswa tunagrahita dan tunarungu, mereka diberikan tugas-tugas sederhana untuk memanggil saat latihan akan dimulai, atau memanggil siswa di kelasnya. Siswa tunagrahita diberikan contoh isyarat sederhana untuk memanggil siswa tunarungu untuk latihan. Begitu pula siswa tunarungu diminta memberitahukan isyarat yang dapat digunakan untuk mengajak latihan bersama.

Pada minggu kedua dan ketiga siswa tunagrahita mulai menunjukkan kepercayaan diri saat diminta guru memanggil teman tunarungu. Walaupun saat istirahat atau bermain belum terlihat kebersamaan antar siswa tunagrahita dan tunarungu. Sampai minggu ke empat pelaksanaan latihan hanya sesekali guru menyaksikan siswa tunagrahita dan tunarungu berkomunikasi.

Pada waktu pengambilan video, siswa tunarungu dan tunagrahita terlihat dapat bekerja sama saat diminta guru untuk membantu jalannya perekaman. Siswa tunarungu dapat meminta teman tunagrahita bantuan dalam proses perekaman dan juga sebaliknya siswa tunagrahita dapat berinisiatif mengajak siswa tunarungu bekerja sama tanpa diminta guru.

Pembuatan drama musikal yang mengharuskan para siswa yang terlibat di 
dalamnya untuk intens berkomunikasi terbukti dapat meningkatkan komunikasi antar siswa tunagrahita dan tunarungu. Peningkatan ini juga dikarenakan proses latihan dan perekaman video yang berlangsung lebih dari satu bulan membuat para siswa terus menerus bertemu dan dapat mempraktikkan bahasa verbal dan non verbal sederhana yang mereka pelajari dari guru ataupun dari teman mereka.

\section{KESIMPULAN}

Faktor pendukung komunikasi antar pribadi antara anak tunagrahita dan tunarungu adalah keadaan lingkungan dan kebutuhan sehari-hari. Melakukan kegiatan bersama-sama menciptakan kebutuhan siswa untuk saling berkomunikasi satu sama lain. Meskipun anak tunagrahita memiliki IQ di bawah rata-rata tapi mereka masih bisa mempelajari dan menggunakan bahasa isyarat sederhana. Sedangkan anak tunarungu dapat berkomunikasi dengan melihat gerakan pada mulut dan juga gerak tubuh selain menggunakan bahasa isyarat untuk berkomunikasi.

Pembuatan proyek yang melibatkan siswa tunagrahita dan tunarungu dalam kurun waktu 1 bulan menunjukkan peningkatan kemampuan dan kepercayaan diri siswa tunagrahita dan tunarungu untuk saling berkomunikasi. Pembuatan proyek drama musikal ini menciptakan kebutuhan bagi siswa tunagrahita dan tunarungu untuk terus menerus bertemu dan saling berkomunikasi. Dengan pendampingan dan dorongan dari guru, siswa terdorong untuk saling berbicara dan meminta bantuan kepada siswa lain sehingga komunikasi mereka dapat terjalin dan meningkat seiring waktu.

\section{DAFTAR PUSTAKA}

Andrani. (2017). Strategi Pembinaan Anak Tunarungu dalam Pengembangan Interaksi Sosial. http://repositori.uinalauddin.ac.id/1403/1/VIVIK\%20A
NDRIANI.PDF, diakses pada Mei 2019

Awalia. (2016). Studi Deskriptif Kemampuan Interaksi Sosial Anak Tunagrahita Ringan. https://jurnalmahasiswa.unesa.ac.id/i ndex.php/jurnal-pendidikan-

khusus/article/view/17924, diakses pada Mei 2019.

Bintoro, T. (2011). KEMAMPUAN KOMUNIKASI ANAK

TUNARUNGU. Perspektif Ilmu Pendidikan, 23(XIV), 12 - 40. https://doi.org/10.21009/PIP.231.2

Cahyaningrum. (2014). Pembentukan Kemampuan Kerjasama Pada Anak Tunagrahita Ringan dalam Pembuatan Batako di SLB Mardi Mulyo Bantul. https://eprints.uny.ac.id/44187/1/091 03244027 ANITA\%20CAHYANIN GRUM.pdf, diakses pada Mei 2019

Lelyana. (2017). Interaksi Sosial Antar Anak Tunarungu dan Anak Tunarungu dan Anak Dengar. https://repository.usd.ac.id/8986/1/1 19114018.pdf, diakses pada Mei 2019

Mudjiyanto. (2018). Pola Komunikasi Siswa Tunarungu di Sekolah Luar Biasa Negeri Bagian B Kota Jayapura.

https://jurnal.kominfo.go.id/index.ph $\mathrm{p} / \mathrm{jskm} /$ article/view/220205, diakses pada Mei 2019

Somantri, S. (2007). Psikologi Anak Luar Biasa. Bandung: PT. Refika Aditama

Sugiyono. (2015). Metode Penelitian Kuantitatif, Kualitatif, dan R\&D. Bandung: Alfabeta. 